\title{
The Relationship between Policy Design and Poverty Reduction: How the Design of Social Protection Programmes Address the Needs of the Poor in Ghana
}

\author{
Joseph Kwame Sarfo-Adu ${ }^{1}$ \\ ${ }^{1}$ Public Administration \& Management, University of Gent, Belgium \\ Correspondence: Joseph Kwame Sarfo-Adu, Public Administration \& Management, University of Gent, Belgium. \\ E-mail: sarfoadujoseph@gmail.com
}

Received: December 20, 2020

Accepted: January 15, 2021

Online Published: February 2, 2021

doi:10.5539/jsd.v14n2p1

URL: https://doi.org/10.5539/jsd.v14n2p1

\begin{abstract}
The implementation of social protection programmes has seen some significant success in poverty reduction among nations. This notwithstanding, there are some challenges in the designing of these programmes that sometimes defeat their intended purposes. For this reason, there is the need for a further consideration on the design of social protection programmes in reaching the poor. This paper assesses how the design of social protection programmes in Ghana takes into consideration the needs of the poor and other intended beneficiaries. The study adopts the concepts of social protection designs by Norton, et al (2001) and the beneficiary-targeting approaches by Rama and Dean (2016) to compare and assess how Ghana's programmes are designed. This is purely a qualitative study that interviewed 20 respondents with adequate knowledge on the design of the social protection programmes. The study revealed that generally, in Ghana, the design processes of social protection programmes adopt more institutional-consultation approach than beneficiary/community-level consultation. On the part of selecting beneficiaries for social protection however, programmes like LEAP, School Feeding and the Capitation Grants were community based, that allow representatives of communities to select beneficiaries for the programme. The design of social protection programmes should be responsive to the needs of their intended beneficiaries, there is therefore, the need for broader consultations with the targeted beneficiaries. Consultations should, hence, not just be limited at the institutional levels.
\end{abstract}

Keywords: poor, vulnerable, targeting, community, beneficiaries

\section{Introduction}

Many African nations especially sub-Saharan Africa countries face the highest regional poverty rate of 40 percent, with 439 million people living below the 1.9\$/day poverty line (Lakner et al., 2019). Global statistics have proven a general fall in the level of poverty, accompanied with a rise in the level of inequality (World bank, 2018). It is due to the persistence, magnitude and depth of poverty and inequality that Social protection programmes gained prominence as an effective policy framework for addressing chronic poverty and vulnerability especially in Latin America and Africa (Commission for Africa, 2005; Fiszbein, \& Yemtsov, 2014).

Some countries, including those in Africa have integrated social protection into national policies and have started to develop and implement legislation on social protection (Kesteren and Gent, 2017). Article 43 the Kenyan constitution, for instance, obliges government to provide appropriate social security to persons who are unable to support themselves and their dependents. There is also the South African Bill of Rights which requires the state to take reasonable legislation within its resources for social protection programmes.

In Ghana, a number of social protection programmes have been initiated over the past two decades, some of which include Health Insurance Scheme (NHIS); Ghana School Feeding Programme (GSFP); Livelihood Empowerment Against Poverty (LEAP); Capitation Grant (CG); and the National Youth Employment Programme (NYEP). Ghana's commitment to social protection is again manifested in the establishment of the Ministry of Gender and Social Protection as well as the implantation of the National Social Protection Strategy (NSPS) which entails different measures that intend to protect people more especially the poor and vulnerable from risks and shocks (NSPS, 2007). 
Despite some chalked successes of these social protection programmes in reducing the prevalence of poverty and vulnerability, it has not escaped the contextual, and conceptual constraints which sometimes defeats the intent of reaching the poor and vulnerable. Fiszbein and Yemtsov (2014) noted that even though almost all developing countries have some form of social protection, very few of the poor and vulnerable population benefit from these programmes. In Ghana, for instance, the LEAP only covers 450,000 households out of the 1,360,000 households who are estimated to be extremely poor (UNICEF, 2020). For this reason, there is the need for a further consideration on the design of social protection programmes in reaching the poor. Unfortunately, the value of policy design has been greatly underrated in the processes of establishing programmes (Hallsworth, 2011). In recent times, there have been initiatives to involve the poor concerning programme design. However, how effectively the "voices of the poor" are integrated into programme design, leaves much to be desired (Cook, Kabeer, \& Suwannarat, 2003).

The ability and willingness to study, measure and analyse poverty and vulnerability are key for designing relevant social protection programmes for the appropriate beneficiaries. Abebrese (2012) revealed that the selection of appropriate beneficiaries for various social protection programmes in Ghana has been a challenge mainly due to the fact that, there are no readily available records on the poor and vulnerable. There are still significant numbers of the poor and vulnerable who are excluded from the benefits of social protection. Issues of how to target the poor and how to measure poverty and neediness are all areas of concerns in the appropriate beneficiaries of social protection programmes. Other programme specific examples like how to define whether somebody has to pay the maximum premium or just the accounted premium for the NHIS and how to assure that solely the needy people receive the LEAP cash transfers all have to be dissolved to ensure fair application of these social protection programmes (Abebrese, 2012).

This paper assesses how the design of social protection programmes in Ghana takes into consideration the needs of the poor and other intended beneficiaries. The study adopts the concepts of social protection designs by Norton, et al (2001) and the beneficiary-targeting approaches by Rama and Dean (2016) to compare and assess how Ghana's programmes are designed. These concepts have been adopted by the study because they have dealt with relevant approaches and issues of designing social protection, which are the main focus of this study. In this study, the functional policy design process model has also been used in discussing social protection designs in Ghana. With this model, we assessed whether social protection programmes in Ghana adopt a grass-root approach and involve intended beneficiaries in its designing process.

\section{Relevant Concepts on Social Protection Design}

\subsection{Defining Social Protection}

Social protection (SP) as a concept has only come into widespread use relatively recently and can be quite elusive in character when the attempts at definition are made. This is because SP has been defined in various ways by different organizations and thus reflects the different objectives and approaches to social protection (See: ILO, 2014; Norton et. al, 2001; Ginneken, 1999). For instance, the ILO (2014) states that "social protection is broadly understood as a set of public and private policies and programmes undertaken by societies in response to various contingencies to offset the absence or substantial reduction of income from work; to provide assistance for families with children; as well as provide people with health care and housing." Social protection is the assistance or help given to those in need or at risk of hardship. It relates with managing, preventing and overcoming situations that unfavorably affect the citizens' well-being. Getubig and Schmidt (1992) have captured Social protection to be “....any kind of collective measures or activities designed to ensure that members of society meet their basic needs (such as adequate nutrition, shelter, health care and clean water supply), as well as being protected from contingencies (such as illness, disability, death, unemployment and old age) to enable them to maintain a standard of living consistent with social norms."

The focus of this study is on the designing of social protection, hence emphasis have been placed on various concepts of designing social protection programmes.

Designing Social Protection Programmes

Principles for Designing Social Protection Policies

Norton, et al (2001) has identified that designing an effective social protection policy must take into consideration;

- The needs, realities as well as the priorities of intended beneficiaries. To this end, good governance, transparency and information play key role in designing social protection programmes (Norton, et al 2001). 
- The engagement of variety of institutions aside those in the public sector that provide social protection functions. This should particularly be the case in developing countries where non-governmental agencies also initiate social protection programmes.

- $\quad$ The need to strike balance between three measures of social protection. These include measures designed to prevent shocks which have a negative impact on the poor; ex ante measures which reduce the impact of such shocks when they happen; and those measures which help those affected to cope once shocks have occurred.

Again, social protection policies or programmes as identified by Norton, et al. should be;

- Responsive to the needs and conditions of livelihood of intended beneficiaries;

- Affordable in the extent that, it does not bring too much burden to the public budget as well as communities and households;

- Financial and Political Sustainable;

- $\quad$ Build and Utilise Capabilities of individuals, households and communities and hence avoiding the creation of dependency and stigma;

- Flexible in responding to changing scenarios and emergence of new challenges.

In designing social protection policies, it should not only be seen as a field that deals with problems of human welfare but also as one which enhances human potential and promotes equality of opportunity. An efficient social protection design should lead to;

- Increasing security through the sustenance of livelihood during economic, political, environmental, health or other shocks as well as reducing the likelihood occurrences of such shocks.

- Contributing to equality through the promotion of sufficient livelihood such as quality education, health and nutrition that will ensure enhanced equality of opportunity for all.

- $\quad$ Promoting growth through the empowerment of individuals and households with productive skills and capabilities.

Social protection policies, when not appropriately designed may undermine any or all of the above (Norton, et al 2001). The use of statutory forms of social insurance for providing pensions and other benefits to workers in uneconomic state enterprises for example, has been shown in practice to enhance inequality in many developing countries, by effectively taxing poorer workers to provide benefits for the non-poor (Ginneken 1999).

Designing policies involves various actors, which may include both governmental and non-governmental agencies. All these actors have various roles they play in the designing process of social protection policies.

\subsection{Actors Involved in policy Making Process}

Policy design involves relevant actor who play crucial and influential roles in the entire processes. These crucial actors in policy making have been categorised into Unofficial and Official policy makers (Anderson, 2003). Unofficial policy makers do not usually occupy formal or political positions, but mostly harness their interest and demands and then influence official policy makers to factor such demands in their policy design process. Official policy makers on the other hand, are those who have the legal authorities to engage in the designing of public policies and include legislators, the executives, administrators, the judiciary and political officials. Anderson (2003) and Egonmwan (1991) further categorise the official policy makers into primary and supplementary policymakers. Primary policy makers are constitutionally mandated and empowered to engage in the formulation of polices, whereas the supplementary policy makers on their part receive authorities from the primary policy makers to participate in policy formulation.

Government takes part in policymaking through top level bureaucrats (the judiciary, legislative, executives, and ministers), middle level bureaucrats (heads of the state departments and their immediate subordinates, civil) and administrators (municipal directors). Most of the social protection programs are supported by foreign donors and proceeds from the national taxes. This will depend on the level of national resources available (Hanlon et al., 2010: 154). Governments can also reallocate expenditure on aid grants or borrowing to support social protection programmes (Grosh et al., 2008).

International Institutions such the IMF, World Bank, ILO and UN organizations, bi-lateral donors, and the world community at large are pivotal actors in policy making (Deacon, Hulse, Stubbs, 1997). They provide donor support, in a form of development assistance through general and sector budget support (Barrientos, 2007). Donor support cannot be depended on in the long-term timeframe, therefore partnership with government may be the best 
approach, and so that donors provide start-up funds and governments gradually take over the support of the programme (Barrientos, 2007; Harris, 2013).

Citizens, households or individuals are also major players in social protection. They are either mostly beneficiaries or contributors to social protection. The second largest source of social protection financing is out-of-pocket expenses paid by citizens. This is mainly the case of Health-related social protection programmes/policies (Barrientos, 2007)

Civil society organisations have much to contribute to the shaping and not just implementation of the policy (Beteille, 2000). This group consists of youth groups, organizations of persons living with disabilities, NGOs, FBOs, the media, researchers, community groups, labor unions, and interest groups. They defend local or sectorial interests, as well as specific values against or beyond the formal political process (Castells, 2008). The involvement of businesses and these civil society groups is necessary if governments are to improve the transparency, quality and effectiveness of their policies, even establishing the legitimacy of the public policy (Hai, 2016).

The selection of beneficiaries for social protection programmes is a key component in the designing process. Appropriate targeting process is needed to select the right beneficiaries of a social protection programme. The study therefore assessed the targeting process of Rama and Dean (2016) and then compared it to that of Ghana.

\subsection{Targeting in Social Protection}

Targeting in social protection has become an important issue for debate among various analysts and practitioners. In low-income countries, especially those in sub-Saharan Africa, where poverty rates are very high with limited fiscal resources, the targeting approach has been highly criticised. Targeting, as argued by critiques requires information to identify poor households which may be difficult and expensive to collect. Again, the administrative capacity to manage a targeted system may be lacking in these low-income countries (UNICEF, 2009). Targeting may also induce social cost such as stigmatisation as well as social tension among recipients and non-recipients (Slater et al., 2009).

Contrary to these critiques, Adato and Hoddinott (2007) see targeting in social protection programmes as means to an end, where the end is ensuring that poor households are the ones who benefit from social protection.

Identifying the target groups for social protection programmes is one of the first aspects of the designing process. Targeting beneficiaries for social protection programmes varies among countries and usually combines number of methods. Rama and Dean (2016), however outlines four (4) primary categories that encompasses most targeting methodologies;

Geographic Methods: This form of targeting is particularly attractive when institutional capacities needed to collect information are low. It is also effective when the poor are usually concentrated in a particular region, district or village. This method however may be politically sensitive as it disburses benefits to some areas but not others.

Proxy-Means Testing (PMT): With this method, the government collects demographic and asset data from households and then use these data to predict income level of such households. Those who pass the PMT are below the poverty line and are enrolled unto the programme.

Self-Targeting: The self-targeting method allows intended beneficiaries to apply for the programme. There is however a barrier to restrict the probability of relatively richer households applying for the programme. When the right restricted barriers are applied, richer households can be effectively screen from the programme. These programmes with self-targeting methods usually have the potential advantage of flexibility that allows households to access them when they have had some form of shocks. One disadvantage here, however, is the difficulty for governments to initially predict in advance the number of people who will actually enrol or participate in the programme providing additional challenges to budgeting and implementation (Rama and Dean, 2016).

Community Based Methods: In this method community members choose those in their locality who are needy to be enrolled into the programme. With this method, the community is incorporated in the determination of the poor within their localities (Seabright, 1996). A potential benefit of this method is that, it makes the programme more popular and acceptable as people may feel that their views were incorporated in the process. This notwithstanding, allowing the community to determine the programme recipients may result in the elites capturing the process.

The involvement of intended beneficiaries of a policy, especially at the designing or initiation stage is crucial to determine the success of such policy. In this study therefore, the Functional Policy Design Process Model, which deal with grass-root participation have been discussed to assess if Ghana's approach is line with this model or vice versa. 


\subsection{The Functional Policy Design Process Model}

This model suggests that formulation of specific policies should always come with alternatives. This, according to proponents of this model will be achieved through grassroots participation towards the policy making process. The model, hence takes into consideration active grassroots participation in the policy making process (Mamburu, 2004). It is a comprehensive and all-inclusive approach aimed at forging collaboration with the policy process. This model, therefore suggest strategies such as consulting actors involved at the grassroots level in the policy process.

According to Dye (1998), the model explains that a policy is a political activity with stages which include identification of problems; setting the agenda; policy formulation; legitimating policy; implementation and evaluation. Functional process model also encourages analysis of policies during the policy making process so as to identify the successes or failures of the policy. The model again suggests that administrators of policies implement effective methods in making sure that policies are successful in improving the lives of communities (Mamburu, 2004).

\section{Methodology}

This research uses a qualitative multiple case study to explore how the design of social protection programs (NHIS, LEAP, SFP, NYEP, and Capitation grant) reduces poverty in Ghana. Qualitative case study resonates well with this study because it provides the tools for a situational, understanding of how the design of the selected programs addresses the needs of the poor (Yin, 2003).

The research uses triangulation of both primary and secondary data sources. The choice of this cross verification of data sources was on the basis that the weakness of one method will be offset by the other and hence a more accurate and dependable data for the research would be obtained. A criterion sampling, a non-probabilistic technique, was used to identify individuals who have knowledge on the design of the selected social protection programs. Twenty 20 respondents were selected for the study. The researcher believes that this number of respondnets enables saturation for the study; adequate data needed to understand the research topic is reached with this number (Seidman, 2006). The study used both primary and secondary data to analyse all the three objectives of the research with the aim of finding the most accurate available answers to questions raised. Semi-structured interviews were conducted with respondents from government officials (ministers, heads of departments, administrators), international institutions (ambassadors), households (community leaders), CSOs (the University Students' association of Ghana (USAG), World Food Programme, Media (Radio Ghana and Joy FM), NGOS (UNICEF, the World Food Program), and researchers (Centre for Social Policy Studies (CSPS) and the Institute of Statistical Social and Economic Research (ISSER)). Refer to Appendix 1 for the number of officials selected from these institutions. Secondary data such as party manifestos, policy documents, legislative instruments, journal articles were used. All interviews were carried out in Ghana over a period of three weeks.

Data from the interview was transcribed and cross-checked to resolve discrepancies. Data were analysed into global themes, organizing themes, and basic themes, with the use of the Nvivo 12 version. To comply with ethical standards, names and positions of interviewees were kept confidential.

\section{Results}

\subsection{Designing Social Protection in Ghana}

All the studied social protection programmes, as obtain from all the study participants, in the county have been designed based on vulnerability and poverty among some sections of the society. These social protection programmes, are hence, geared towards improving access to some social services among the poor and vulnerable and thereby reducing the inequality gap within the society. The Capitation Grants (GC) was for instance to enable children from poor households get access to basic education. Speaking on this, an official at the Ghana Education Service (GES) indicated '......Some parents could not afford the levies charged by the schools. Because of that, when those children go to school, they were sacked. So in a way, some people were being prevented from accessing education. This, among others informed the design of the Capitation Grants that absorb all forms of levies that parents were paying at the basic level....' (refer to appendix 3)

The design of other programmes like the health insurance and the LEAP have all been informed by the need to realising the burdens of the poor and the vulnerable. The difficulty of the poor in accessing health care services during the era of the 'Cash and Carry System' prompted the design of the National Health Insurance Scheme which made it possible for some poor household to access basic health care services. The LEAP on its part is to essentially take care of the poor and the vulnerable. A research fellow the study interviewed, in buttressing the programme 
and its design for the poor mentioned '...The thinking behind the LEAP was that, a direct cash transfer to the extreme poor could help them smoothen consumption and then perhaps build their capabilities overtime....'

The rapid rise of unemployment among the youth was the main basis of the design of the National Youth Employment Programme (refer to appendix 2). The Programme, according to an official of the National Youth Authority was intended to address agitations of the young people who either have skills or have completed school but are not having any work, and those who had no skills at all but were migrating from the villages to the regional capitals such as Accra, Kumasi, Takoradi to work, (refer to Appendix 3).

\subsection{Social Protection Designs and the Needs of the Intended Beneficiaries (the Poor)}

Taken into consideration the needs of intended beneficiaries of a programme, will require a broad consultation of these beneficiaries during the designing phase of the programme. At the institutional levels some forms of consultations were made in the design of social protection programmes. The Ministry of Youth and Employment as well as the National Youth Authority, as identified by the study, were for instance, consulted in the design of the Youth Employment Programme. This, notwithstanding, the level of consultation at the community level, were the real beneficiaries (unemployed youth) of the programme are located was identified to be minimal. Confirming this, a research fellow the study interviewed stated '...but as to how wide or how deep the consultation was, is the problem. Because consulting ministries and department, and leaving the key stakeholders for who the program was developed, is a problem. Now talking about how deep, we need to look at how the consultation process even took place actually; was it a bottom-top approach or a top-down approach. All these things need to be looked at in the program design, and how effective it will be later on.'

The design of the Capitation Grants, according to the study took into consideration the needs of the public basic schools through a consultation process that look at some budgetary items of these schools. The design of the programme hence ensured that it aligned to the expenditures of these public basic schools where the project beneficiaries are located. The National Health Insurance Scheme (NHIS) was designed as a pro poor social intervention programme. In this regard, it is seen as a programme for the poor. A representative of the Ministry of Health mentioned '...The problem that was seen when we were doing the cash and carry where the poor had difficulty in accessing health services have been minimised by NHIS...' In an interview with the Ghana Federation of Disability Organisation, it was identified that consultation with the organisation in the design of the National Health Insurance for instance, was not as wide as expected. '.... The consultation process was not exhaustive enough. You know some of these policies too came at a rush and normally the government has a position before even the public comes in, so your input might not necessarily be able to influence so much...'

According to a representative from a relevant stakeholder institution the study interviewed, the designing of programmes such as the LEAP and the SFP usually takes place at the national level, with less or no consultation at the community level, where the intended beneficiaries are. With the LEAP, for instance, the representative mentioned '.... Intended beneficiaries only come to targeting centres where they complete forms that will be submitted to Accra. They don't decide how the selection is done; how much to be paid, among others. Most of the consultations to decide on the designing of the programme are done at the national level.

\subsection{Targeting/Selecting Social Protection Beneficiaries}

Social protection programmes usually target households or individuals who are unable to afford some basic social services. A general categorization of the poor is pegged as households who live below 1 dollar a day. Aside poverty and vulnerability, selection of beneficiaries for social protection programmes takes into consideration the availability of funds for these programmes. Funds availability is a key influential factor in the designing of social protection programmes.

In selecting beneficiaries for the LEAP, for instance, not all poor household were able to benefit from the programme. This, according to a respondent at the Social Welfare department was due to the fact that government did not have the financial capacity to deal with all poor household. With this effect, the extremely poor were further categorised to be the intended beneficiaries for the programme. '...Even with the extremely poor households, the number is too large for the government to undertake. So due to this, government do a targeted programme to select beneficiaries for the LEAP. Within the targeting, these is even a categorical targeting, where the attention is placed on category of people/household within the extremely poor groups...' A representative at the social welfare departed noted.

The LEAP hence targets category of people from extremely poor households such as orphaned vulnerable children; persons with severe disabilities; the aged (65 years and above) without productive capacity and support; and pregnant women with children under 12 months. Targeting for beneficiaries for the LEAP programme start at the 
national level, where LEAP Secretariat coordinate with other institutions such as the Ghana Statistical Service to identify poor regions, districts as well as communities within these districts. At the community level there is the Community LEAP Implementation Committee (CLIC) that is made up of a maximum of nine (9) and minimum of five (5) of well-respected and opinion leaders in the community. Members of the CLICs usually include traditional leaders, district assembly members, teachers and nurses, religious leaders and other community leaders. The CLIC helps in identifying targeted beneficiaries that falls within the four categories of the programme. After identifying these targets/households, a proxy-means testing questionnaires are administered by social welfare officers in the respective districts (refer to appendix 2). These questionnaires generally identify characteristics of selected households. Data on the household are forwarded into the registry of the LEAP Secretariat to finalise the actual beneficiaries of the programme. The final lists of beneficiaries are then sent back to the CLIC within the communities for approval.

The National Health Insurance Scheme is opened to all Ghanaians who register to the scheme, with the payment of annual premiums. There are however, some exempts group which do not have to pay towards the scheme and this constitute about 70 percent of all registered members. For the purpose of this study, analysis on targeting is based on these exempts groups of the scheme. Categories of individuals targeted for exemption include dependent children below 18 years whose parents are already members of the scheme. Others include individuals above 70 years, as well as all pensioners from SSNIT. The last set of exemption categories are indigents who are within the 'poor group' defined by the scheme's regulations. Specifically, according to regulation 58 of the scheme, " $A$ person shall not be classified as an indigent under a district scheme unless that person (a) is unemployed and has no visible source of income; (b) does not have a fixed place of residence according to standards determined by the scheme; (c) does not live with a person who is employed and who has a fixed place of residence; and (d) does not have any identifiable consistent support from another person."

These exemption-targeting procedures of the scheme are fairly good but with some challenges that can prevent some extremely poor individuals and vulnerable from benefiting. In the words of a respondent from the social welfare department the study interviewed '......So you see, even though the exemption procedure is good, there are still some challenges. Let's take for instance a child who is below 18 years and whose parents are not members of the scheme. What this means is that, such a child will also automatically not be able to benefit from the scheme. But you know it is not this child's fault that his parents are not registered members.....' Again, the schemes definition of a 'poor indigent' is seen not be comprehensive enough to capture many poor individuals. A research fellow who was a respondent of the study confirming this stated, '...The definition of a poor indigent by the scheme can be a bit problematic, since a working poor would not in principle qualify even if his or her income were very low. The lack or residence is also a rather stringent criteria and the combination of both criteria may explain why only very few individuals have been accepted into the scheme as indigent....'

Other programmes like NYEP essentially targets the youth during its design. The scope however is limited to youth with at least a Junior High School Certificate. This approach hence, exclude many youth among the poor without a Junior High School education. Selecting beneficiaries for the School Feeding Programme (SFP) takes into consideration among others, the poverty as well as commitment levels of intended communities. Targeting criteria for selecting beneficiary communities for the programme include;

- Willingness of a community to provide basic infrastructure (e.g. kitchen, store, dining room);

- Commitment of the District Assembly, demonstrated by its interest to sustain the programme;

- Poverty status of the district and community;

- Low school enrolment and/or attendance and gender parity index;

- High drop-out rates;

- Low literacy levels;

- Presence of planned health and nutritional interventions or expansion of existing ones;

- No participation in an already existing SFP;

- High community spirit and management capability

The communities' involvement in the SFP is critical hence their capabilities and commitment being critical elements in the selection process. The study's respondent in the Gender Ministry, for instance, confirm this with her statement '......Even though we look at poverty situations at the community levels in selecting beneficiaries for the programme, we also consider with high degree the willingness and commitment of community leaders and the 
community in general before selecting them to be beneficiary community for the project. We do this because for the programme needs to be sustainable, we need the community to be on board....'

\subsection{Actors in the Design of Social Protection Programmes in Ghana}

The design of social protection programmes in Ghana involves various actors including both public and private institutions. This study generally identified four (4) main actors in the design of social protection programmes;

- Government and its agencies

- International Institutions

- Private Institutions (such us Research/academia; civil society organisation; the media; etc)

- Individuals and Households

The roles of these institutions are broadly grouped by the study into four (4), which include (refer to Appendix 2);

- Defending Sectorial Interest

- $\quad$ Policy Making

- Donor Support

- Expenditure Reallocation; and

\section{Defending Sectorial Interest}

In the design of programs, the interest of the main beneficiaries for whom these programs are designed need to be protected to ensure that the programs benefit them efficiently. This is mainly done by government through its sector ministries as well as some private institutions like Civil Society Organisations (CSOs). One of such institutions is the Ghana National Education Campaign Coalition (GNECC) which monitor the education system and make known the various ways of providing assistance. Defending sectorial interest can also be in the form of sensitization of beneficiaries to understand the need for such programs and their roles in ensuring the success of these programs. This notwithstanding, some of these institutions the study interviewed like the media and academic/think tanks believe that in most instances, their roles of defending the interest of beneficiaries during the designing of programmes are usually relegated by government. '.... In most instances, media for example takes no role in the program design; rather government designs the programs and then calls on media later to broadcast it. This means that we just disseminate what has been decided by government without our input...' a media respondent indicated. This view was not very different from the academia which believes that the gap between evidence in academia and programs design seem to be widening.

\section{Policy Making/Designing}

Government also plays important role in designing policies. Government does this through its ministries and agencies. The ministry of employment for example discusses the issues of youth unemployment through stakeholders' meeting and the decisions made are channelled to cabinet and further on to parliament, which when accepted leads to the establishment of programs. The Ghana Education Service (GES), one of government's agencies is leading the design of the base grant, a policy which it intends to roll out in conjunction with the capitation grant. GES is able to do this through its steering role of the Annual Education Sector Review (AESER) where all partners in the education sector such as the civil service, donor partners like UNICEF, DFID and others all come together to have a review.

\section{Expenditure Reallocation}

Providing funds and distributing funds for the design of the programs was a role played especially by government, according to respondents. Government usually does this through its sector ministries and agencies. In the case of the National Youth Employment Program (NYEP), the National Youth Authority (NYA) acting in place of government played a steering role in the committee of stakeholders to design the program.

\section{Donor Support}

International institutions provide donor support to the design of programs, which can be in the form of cash or in other instances technical support. Along the line, some donor supports reduce or ceases as in the case of Capitation grant. Such supports, however, cannot be depended on in the long-term, hence partnership with government may be the best approach, so that donors provide start-up funds and governments gradually take over the support of the programme. 


\section{Discussions}

Designing social protection programmes is as much critical like their implementation. There are strong correlations between an appropriate design and effective implementation. All things being equal, an efficient social protection design will result to a successful implementation of such programmes and vice versa.

The design of social protection programmes in Ghana, as identified by the study are informed by the need to reducing the burden of the poor and vulnerable within the society. Programmes like LEAP and the Capitation Grants are all geared towards providing some relief for poor households and individuals. The NHIS is aimed at enhancing access to basic health care services for the poor, whereas the NYEP intends provide unemployed youth with some form of income and skills. To this end, these programmes in Ghana can be seen as responsive to the needs and livelihood of their intended beneficiaries and hence, corresponding to the responsiveness assertion of social protection programmes by Norton, et al (2001).

Norton, et al (2001) in discussing the principles of effective social protection designs outlined that, the needs and priorities of intended beneficiaries should be taken into consideration in the design process. This requires broad consultation of targeted beneficiaries in the design processes. This study however revealed that, broad consultation of real beneficiaries most often at the community level were lacking in the design processes of most of these social protection programmes. With the exception of the Capitation Grants where the study revealed there were some broad consultation process that took into consideration budgetary items of beneficiary schools, other programmes lacked this broad consultation. The NYEP, even though had some institutional consultations at the national level during its design, same was not seen at the community levels where the youth who are real beneficiaries of the programme are located. '... How can you say you are designing a programme for the youth and your refuse to have an extensive consultation with the youth who are beneficiaries of your programme?' a research fellow in an interview asked. Other programmes like the LEAP and the NHIS, as indicted by the study respondents lacked extensive consultation with the intended beneficiaries during the designing stage.

Selecting targets for social protection programmes is usually based on poverty and vulnerability as well as the quantum of funds available. Various methods for targeting social protection beneficiaries exist, but this study's focus was on that by Rama and Dean (2016). Comparatively, the LEAP adopts the combination of the Geographic Methods; the Community-Based Methods and the Proxy-Means Testing (PMT) Methods in the selection of beneficiaries. With the geographic method, the LEAP Secretariat in consultation with other institutions such as the Ghana Statistical Service (GSS) identify poor geographic regions and communities where beneficiaries are selected. The Proxy-Means Testing methods are then used to sample out actual beneficiaries where some questionnaires on household characteristics and assets are administered to potential beneficiaries with the help of the social welfare department and the Community LEAP Implementation Committees (CLICs). The LEAP secretariat, based on these questionnaires then select the programme's beneficiaries with approval form the CLIC. The involvement of the CLIC allows the community members themselves, through representatives to identify members to the programme. This is in line with the Community-Based methods as identified by Rams and Dean (2016). The adoption of these three targeting approaches, makes the LEAP one of the best targeted programmes in the country.

The NHIS is in line with the Self-Targeting approach as it allows intended beneficiaries to apply for the programme. One disadvantage of the self-targeting approach, as outlined by Rama and Dean (2016) and which also manifest in the case of Ghana's NHIS, is the difficulty of government to initially predict in advance the number of people who will be enrolled into the programme. This, in most cases poses budgetary challenges that consequently affects the smooth implementation of the programme.

Targeting beneficiary schools for the School Feeding Programme also to some large extent, adopts the Geographical and Community-Based Methods. There is firsts concentration at poor geographical regions or locations and a strong display of communities' readiness and willingness to support the programme.

The study again compared the designing of social protection programmes in Ghana with the functional policy design model, which calls for grass-root participation towards policy making process. Generally, in designing of programmes like LEAP, the School Feeding Programme, NHIS and the NYEP, there are less extensive consultation with grass-root beneficiaries of the programmes. The study, however, identified that the selecting or targeting of beneficiaries of programmes such as LEAP, School Feeding and the Capitation Grants adopts community- based selection processes that brings on board some level of consultations at the grass-root as proposed by the Functional Policy Design Model. 


\section{Conclusion}

Designing a social protection programme is as critical as its implementation. Adequate measures are hence needed to ensure appropriate designing processes that will contribute significantly to a successful implementation of the programme. Generally, in Ghana, the design processes of social protection programmes adopt more institutionalconsultation approach than beneficiary/community-level consultation. Even though institutional consultation and engagement is key for effective social protection designs, the involvement of the intended beneficiaries at initial stages of designing is also important to ensure that design of these programmes reflect the needs and reality of the beneficiaries. Broad consultation with targeted beneficiaries at the community levels as in the case of programs such LEAP and School Feeding should be encouraged.

\section{References}

Abebrese, J. (2012). Social Protection in Ghana: An Overview of Existing Programmes and their Prospects and Challenges. Retrieved December 6, 2019, from http://library.fes.de/pdf-files/bueros/ghana/10497.pdf

Adato, M., \& Hoddinott, J. (2007). Conditional Cash Transfer Programs: A 'Magic Bullet'for Reducing Poverty? IFPRI.

Anderson, J. E. (2003). Public policymaking: An introduction. Boston: Houghton Mifflin Company.

Barrientos, A. (2007). Poverty Reduction and Policy Regimes. Thematic Paper: Social Policy and Development.

Cook, S., Kabeer, N., \& Suwannarat, G. (2003). Social protection in Asia. Har-Anand Publications.

Deacon, B., Hulse, M., \& Stubbs, P. (1997). Global Social Policy-International Organizations and the Future of Welfare. London: Sage Publications.

Egonmwan, J. A. (1991). Public Policy Analysis: Concepts and Applications. Benin City.

Fiszbein, A., \& Yemtsov, R. (2014). Social Protection and Poverty Reduction: Global Patterns and Some Targets. World Development, 61, 167-177. https://doi.org/10.1016/j.worlddev.2014.04.010

Grosh, M., Ninno, C. D., Tesliuc, E., \& Ouerghi, A. (2008). For protection and promotion: The design and implementation of effective safety nets. The World Bank. https://doi.org/10.1596/978-0-8213-7581-5

Hai, D. P. (2016). Process of Public Policy Formulation in Developing Countries.

Hallsworth, M. (2011). Policy - Making in the Real World. Political Insight, 2(1), 10-12. https://doi.org/10.1111/j.2041-9066.2011.00051.x

Hanlon, J., Barrientos, A., \& Hulme, D. (2010). Just Give Money to the Poor: The Development Revolution from the Global South. Sterling, VA: Kumarian Press.

Harris, E. (2013). Financing social protection floors: Considerations of fiscal space. International Social Security Review, 66(3-4), 111-143. https://doi.org/10.1111/issr.12021

International Labour Organisation. (2015). World Employment Social Outlook. Geneva; ILO.

Kesteren, F., \& Gent, S. (2017). National Policy Frameworks for Social Protection in Africa.

Lakner, C., Gerszon Mahler, D., Negre, M., \& Beer Prydz, E. (2019). How much does reducing inequality matter for global poverty? World Bank Group Policy Research Working Paper 8869. https://doi.org/10.1596/18139450-8869

Ministry of Gender, Children and Social Protection. (2015). Ghana National Social Protection Policy.

Norton, A., Conway, T., \& Foster, M. (2001). Social Protection Concepts and Approaches: Implications for Policy and Practice in International Development. ODI Working Paper Number 143, London.

Rama, H., \& Dean, K. (2016). Designing Social Protection Programs: Using Theory and Experimentation to Understand how to Help Combat Poverty. Harvard University.

Seabright, P. (1996). Accountability and Decentralisation in Government: An Incomplete Contracts Model. European Economic Review, 40(1), 61-89. https://doi.org/10.1016/0014-2921(95)00055-0

Slater, R., \& Farrington, J. (2009). Making Social Transfers Appropriate, Achievable and Acceptable: A Practical Tool for Good Targeting. London: ODI.

UNICEF. (2020). Ghana Social Protection Database: Social Protection Budget Brief.

World Bank. (2018). Overcoming Poverty and Inequality: An Assessment of Drivers, Constraints and Opportunities. The World Bank. 


\section{Appendices}

Appendix 1. Sample list

\begin{tabular}{|c|c|c|c|c|}
\hline Actors & Offices & Program & $\begin{array}{l}\text { Selected } \\
\text { Number } \\
\text { respondents }\end{array}$ & $\begin{array}{cc} & \text { Respondent } \\
\text { of } & \text { I.D }\end{array}$ \\
\hline \multirow{4}{*}{ Ministerial office } & Gender and Social Protection & LEAP, SFP & 1 & R1 \\
\hline & Health & NHIS & 1 & R2 \\
\hline & Employment and Labour Relations & NYEP & 1 & R3 \\
\hline & Education. & Capitation grant & 1 & R4 \\
\hline \multirow[t]{4}{*}{ Heads of department } & National Youth Authority & NYEP & 1 & R5 \\
\hline & Social Welfare, & LEAP, SFP & 1 & R6 \\
\hline & Ghana Health Service and & NHIS & 1 & R7 \\
\hline & Ghana Education Service (GES) & Capitation grant & 1 & $\mathrm{R} 8$ \\
\hline Development partners & Ambassador for the Netherlands & SFP & 1 & \\
\hline \multirow[t]{2}{*}{ CSOs } & Association leaders: USAG & NYEP & 1 & R9 \\
\hline & GFDO & LEAP & 1 & R10 \\
\hline \multirow[t]{2}{*}{ Media } & Radio Ghana & All programs & 1 & R11 \\
\hline & Joy fm & All programs & 1 & R12 \\
\hline \multirow[t]{3}{*}{ NGO } & UNICEF & LEAP, SFP & 1 & R13 \\
\hline & STAR-Ghana & SFP & 1 & \\
\hline & World Food Program & Capitation grant & 1 & R14 \\
\hline \multirow[t]{4}{*}{ Research Institutions } & CSPS 1 & All programs & 2 & R15 \\
\hline & CSPS 2 & & & R16 \\
\hline & ISSER1 & All programs & 2 & R17 \\
\hline & ISSER 2 & & & R18 \\
\hline
\end{tabular}

Appendix 2. Coding frequency on how the design of Social Protection Programs address the needs of the poor in Ghana

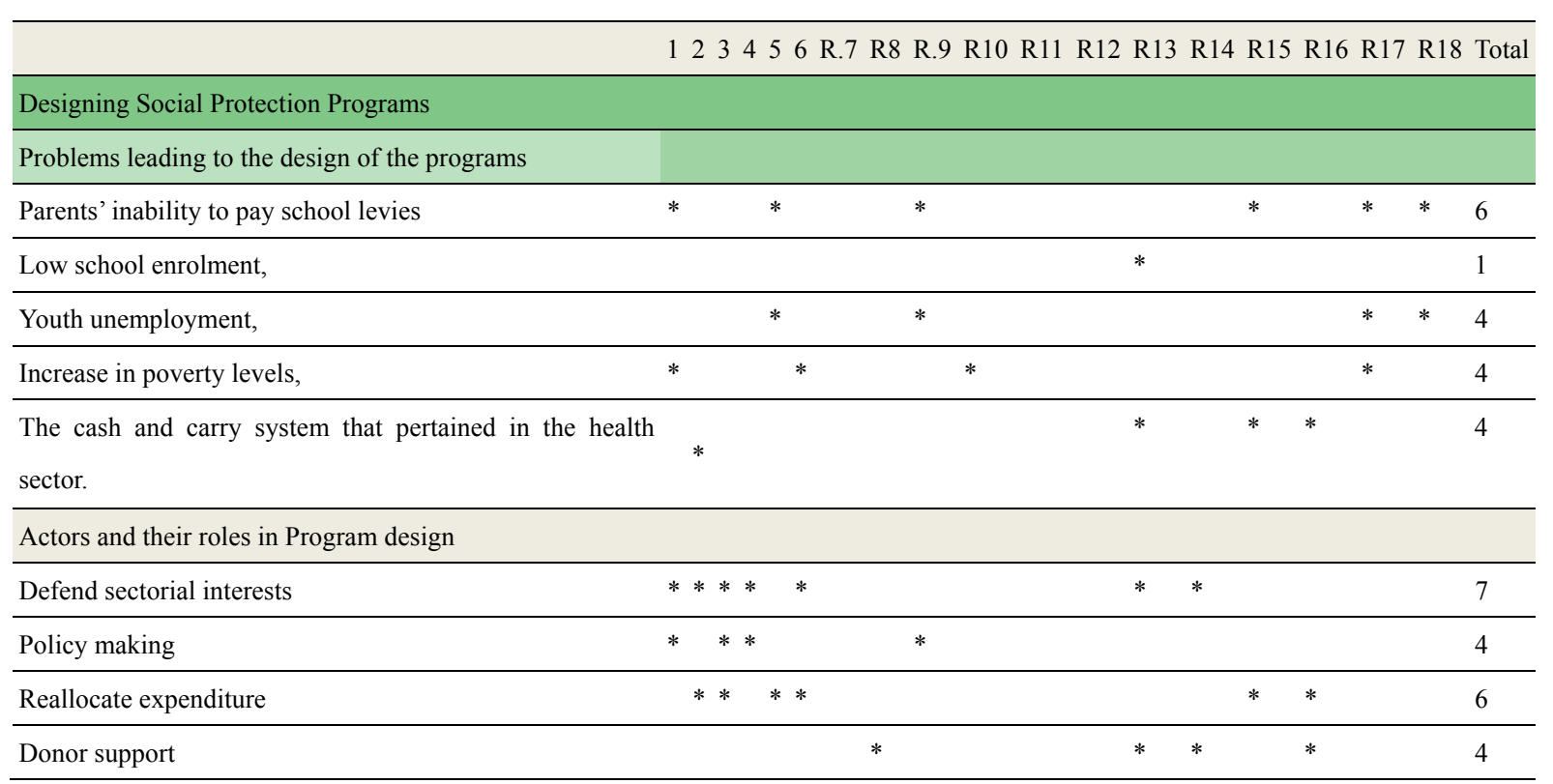




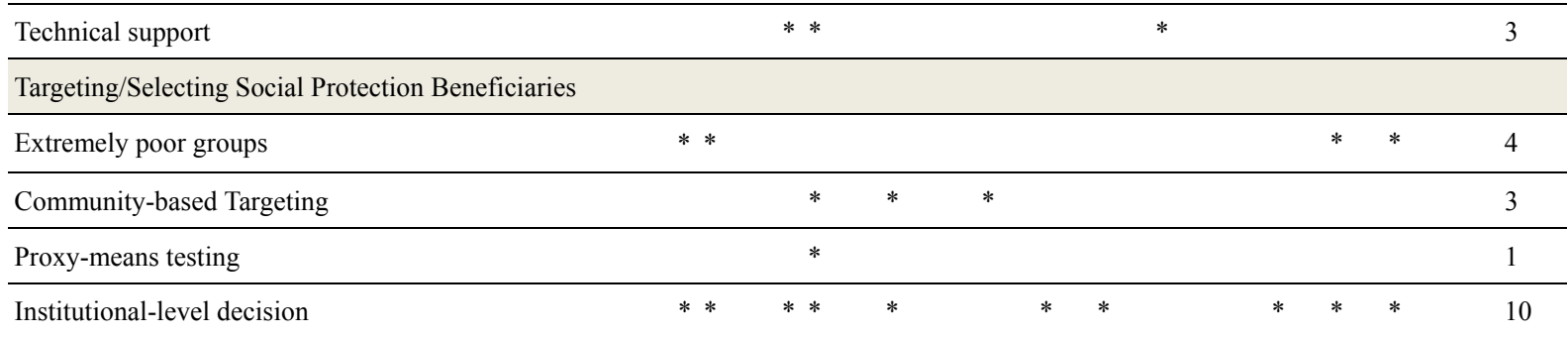

Appendix 3. Thematic framework for how the design of policy programmes address the needs of the poor in Ghana

\begin{tabular}{|c|c|c|c|c|c|}
\hline Parent node & Child node & Grandchild node & Description & frequency & Quotes \\
\hline \multirow[t]{2}{*}{$\begin{array}{l}\text { Designing } \\
\text { Social } \\
\text { Protection }\end{array}$} & $\begin{array}{c}\text { Problems } \\
\text { leading to the } \\
\text { design of the } \\
\text { programs }\end{array}$ & $\begin{array}{c}\text { Parents' inability } \\
\text { to pay school } \\
\text { levies }\end{array}$ & $\begin{array}{l}\text { Parents were } \\
\text { unable to pay } \\
\text { school levies }\end{array}$ & 66 & $\begin{array}{l}\text { Some parents could not afford the levies } \\
\text { charged by the schools. Because of that, when } \\
\text { those children go to school, they are sacked. So } \\
\text { in a way, some people were being prevented } \\
\text { from accessing education. This, among others } \\
\text { informed the design of the Capitation Grants } \\
\text { that absorb all forms of levies that parents were } \\
\text { paying at the basic level.... }\end{array}$ \\
\hline & & $\begin{array}{c}\text { Youth } \\
\text { unemployment, }\end{array}$ & $\begin{array}{l}\text { Inability of the } \\
\text { youth to find } \\
\text { jobs to do }\end{array}$ & 44 & $\begin{array}{c}\text { "...was intended to address agitations of the } \\
\text { young people who either have skills, have } \\
\text { completed school but are not having any work, } \\
\text { and those who had no skills at all but were } \\
\text { migrating from the villages to the regional } \\
\text { capitals to work, such as Accra, Kumasi, } \\
\text { Takoradi. }\end{array}$ \\
\hline
\end{tabular}

\begin{tabular}{|c|c|c|c|c|c|}
\hline & & $\begin{array}{c}\text { Increase in } \\
\text { poverty levels, }\end{array}$ & $\begin{array}{c}\text { Widening } \\
\text { poverty gap } \\
\text { among citizens }\end{array}$ & 44 & $\begin{array}{l}\text { The thinking behind the LEAP was that, a direct } \\
\text { cash transfer to the extreme poor could help } \\
\text { them smoothen consumption and then perhaps } \\
\text { build their capabilities overtime.... }\end{array}$ \\
\hline & & $\begin{array}{l}\text { The cash and carry } \\
\text { system that } \\
\text { pertained in the } \\
\text { health sector. }\end{array}$ & $\begin{array}{l}\text { Payment before } \\
\text { health service is } \\
\text { rendered }\end{array}$ & 44 & $\begin{array}{l}\text { “... The introduction of the user scheme which } \\
\text { we popularly called the cash and carry in our } \\
\text { healthcare delivery system was around the } \\
1980 \text { 's. Actually it created a financial barrier for } \\
\text { access to healthcare among poor households, } \\
\text { that was a problem because if you had money, } \\
\text { the cash and carry serves but if not, one couldn't } \\
\text { access the service..." Ministry of Health }\end{array}$ \\
\hline \multirow[t]{2}{*}{$\begin{array}{l}\text { Actors and } \\
\text { their roles } \\
\text { in Program } \\
\text { design }\end{array}$} & $\begin{array}{l}\text { Defend } \\
\text { sectorial } \\
\text { interests }\end{array}$ & & $\begin{array}{l}\text { Sensitizing of } \\
\text { beneficiaries to } \\
\text { understand the } \\
\text { need for such } \\
\text { programs }\end{array}$ & 77 & $\begin{array}{c}\text { Some of the C.S.Os are Faith Based } \\
\text { Organizations, Community Based } \\
\text { Organizations. C.S.Os do more of sensitization } \\
\text { and ownership for which they also do much of } \\
\text { the social responsibility and social } \\
\text { accountability..." Social welfare }\end{array}$ \\
\hline & $\begin{array}{l}\text { Policy } \\
\text { making }\end{array}$ & & $\begin{array}{c}\text { Design policies } \\
\text { to guide } \\
\text { programs }\end{array}$ & 44 & $\begin{array}{l}\text { So every year, in education, we have what we } \\
\text { call \{AESER\}; Annual Education Sector } \\
\text { Review. Where all partners in the education } \\
\text { sector such as the civil service, donor partners } \\
\text { like UNICEF, DFID and others all come } \\
\text { together to have a review. So at least we have } \\
\text { those consultations and those } \\
\text { engagements...GES }\end{array}$ \\
\hline & $\begin{array}{l}\text { Reallocate } \\
\text { expenditure }\end{array}$ & & $\begin{array}{l}\text { Providing and } \\
\text { distributing } \\
\text { funds for the } \\
\text { design of } \\
\text { programs }\end{array}$ & 66 & $\begin{array}{l}\text { Now the NYA played two roles on the } \\
\text { committee; helping to design the programme, } \\
\text { and by then, we had a youth fund. The youth } \\
\text { fund was made part of the overall initial fund } \\
\text { that was put in place by government to start the }\end{array}$ \\
\hline
\end{tabular}


programme..." National Youth Authority

\begin{tabular}{cccc}
\hline $\begin{array}{c}\text { Donor } \\
\text { support }\end{array}$ & $\begin{array}{c}\text { Provision of } \\
\text { funds by } \\
\text { International } \\
\text { agencies to } \\
\text { guide program } \\
\text { design }\end{array}$ & $\begin{array}{c}\text { I think the original funding was also from... I } \\
\text { forgot the donors that, I've forgotten the } \\
\text { particular donor that gave very huge amount } \\
\text { with SFP, but the World Food Programme } \\
\text { (WFP) also supported by providing us with } \\
\text { support for food, initially. The World bank also } \\
\text { supported I think Health insurance. So as you } \\
\text { can see most of the international agencies came } \\
\text { in in the means of financial support...CSPS }\end{array}$ \\
\hline $\begin{array}{c}\text { Technical } \\
\text { support }\end{array}$ & $\begin{array}{c}\text { I.T services } \\
\text { provided for the } \\
\text { design of } \\
\text { programs }\end{array}$ & $\begin{array}{c}\text { We were not involved in the design at all } \\
\text { because we work with government to provide } \\
\text { technical assistance and finances. So we help } \\
\text { government to expand because we pilot and } \\
\text { improve operations. We have been helping } \\
\text { LEAP. Some of the problem is that wealth is not } \\
\text { shared equally...UNICEF }\end{array}$ \\
\hline
\end{tabular}

\section{Copyrights}

Copyright for this article is retained by the author(s), with first publication rights granted to the journal.

This is an open-access article distributed under the terms and conditions of the Creative Commons Attribution license (http://creativecommons.org/licenses/by/4.0/). 